RESEARCH ARTICLE

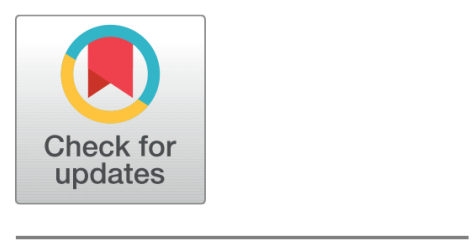

6 OPEN ACCESS

Received: 09-05-2020

Accepted: 23-05-2020

Published: 18-06-2020

Editor: Dr. Natarajan Gajendran

Citation: Mukherjee A (2020) Seasonal variations of zooplankton diversity in fresh water reservoir of West Bengal, India. Indian Journal of Science and Technology 13(20): 1991-1997. https://doi.org/ 10.17485/IJST/v13i20.556

*Corresponding author. Avijit Mukherjee

Department of Zoology, Netaji Mahavidyalaya, Arambagh, West Bengal, India. Tel.: +91-9434313601 avimukh77@gmail.com

Funding: None

Competing Interests: None

Copyright: @ 2020 Mukherjee. This is an open access article distributed under the terms of the Creative Commons Attribution License, which permits unrestricted use, distribution, and reproduction in any medium, provided the original author and source are credited.

Published By Indian Society for Education and Environment (iSee)

\section{Seasonal variations of zooplankton diversity in fresh water reservoir of West Bengal, India}

\author{
Avijit Mukherjee ${ }^{1 *}$ \\ 1 Department of Zoology, Netaji Mahavidyalaya, Arambagh, West Bengal, India. Tel.: +91- \\ 9434313601
}

\begin{abstract}
Background/Objective: Present study was carried out to identify zooplankton density at Baburpukur pond along with physicochemical properties. In India. Planktonic richness reflects the biodiversity stock. The present study assumes greater importance for biodiversity conservation/ pollution indicator and aquaculture of fish and prawns. Methods/Statistical analysis: Statistical analysis in this experiment was performed by Student's t-test. In this test, 0.05 probability, degree of freedom, critical t-value, and calculated t-values were recorded. Here zooplankton number along with physico-chemical parameters was recorded. From these t-values, significant seasonal variations were found in the respective water body. The zooplankton density and physiochemical parameters were recorded during the period of Jun 2018 to February 2020. Diversity of zooplankton has been counted using Sedgwick-Rafter counting chamber. Findings: Four different species of zooplankton were studied such as Daphnia, Cyclops, Cypris and Brachionus. Zooplankton community structure generally changes with temperature, $\mathrm{pH}$ of water, free $\mathrm{CO}_{2}$ level, dissolved $\mathrm{O}_{2}$. This study also reveals that zooplanktons have their own peak periods of density which is influenced by the above environmental conditions. Application: At present, this water reservoir is suitable for fish culturing. So several management practices are necessary to conserve this zooplankton density for proper healthy situation of water body. This study is also helpful in understanding the zooplankton diversity of Baburpukur Pond with proper maintaining of aquaculture.
\end{abstract}

Keywords: Zooplankton; biodiversity conservation; pollution indicator; aquaculture

\section{Introduction}

Presence of zooplankton in water body helps to increase economically important fish populations and they play a major role in energy transfer between phytoplankton and fish ${ }^{(1)}$. The study of freshwater zooplankton fauna is wide 
and complicated process because physical, geographical, environmental and some chemical indicators influence their existence ${ }^{(2)}$. Because they live in freshwater, these freshwater habitats are among the most threatened ecosystem of Earth ${ }^{(3)}$, and majority of these losses comes from anthropogenic activities. Zooplankton diversity is also influenced by the presence of phytoplankton for outcome of nutrients for better survival in aquatic life. Zooplanktons feed on phytoplanktons and facilitate the conversion of plant substance into animal tissue and in turn constitute the basic food for higher animals including fishes, particularly their larvae. Many bigger forms of zooplankton feed on their own smaller community and thus forms secondary consumers, some of them are organic substance feeder lying on the bottom sediment ${ }^{(4)}$ and many others demonstrated that zooplankton study of any water body establishes the present health status of that region. Fluctuations in zooplankton community composition and species diversity can indicate their distribution in any environment; it also acts as an indicator of ecological state of water body related to changes in nutrient concentration and climatic conditions ${ }^{(5,6)}$. If the habitat of zooplankton community changes with the relative environmental conditions, there is a corresponding change in their population number, so they are used as monitoring tool in any aquatic ecosystem and acts as an important ecological inidcator ${ }^{(7,8)}$. Due to their central position in the food web of aquatic ecosystem, several researchers around the world are attracted to study their role in the ecosystem ${ }^{(9)}$. So understanding their various roles and predicting future changes in the ecosystem are becoming increasingly important area ${ }^{(10)}$. Throughout India a number of studies have been carried out about the ecological conditions of freshwater bodies ${ }^{(11-13)}$. The present investigation is an attempt to identify zooplankton density with physico-chemical parameters of the Baburpukur pond.

\section{Methodology}

\subsection{Study area}

The Baburpukur $\left(23^{\circ} 15^{\prime} 35.9172 ” \mathrm{~N}\right.$ and $\left.87^{\circ} 52^{\prime} 34.7520^{\prime \prime} \mathrm{E}\right)$ pond is located in Burdwan town, West Bengal, India, near Sishuniketan School. The temperature of water was also recorded. The total area of the pond is about 0.20 hectare and average depth is $7 \mathrm{~m}$. The pond is surrounded by some trees and walking path. During monsoon, it is filled up with rain water. A part of pond is regularly used for dumping domestic wastes and it is regularly used for bathing.

\subsubsection{Sampling time}

Zooplankton samples were collected for a period of July 2018 to February 2020 from the pond between 5.30 a.m. to 8.30 a.m. For quantitative analysis of zooplankton, $100 \mathrm{~L}$ of pond water were filtered through zooplankton net (mesh size $60-75 \mu \mathrm{m}$ ) and then plankton biomasses were transferred to the specimen bottles (preserved with $5 \%$ freshly prepared formalin). Other fixatives occasionally used are picric acid, ethanol, acetic acid etc. These were then taken to the laboratory and separated group wise using a dissecting microscope and then the specimens were mounted on microscopic slides on a drop of $20 \%$ glycerin after staining with eosin.

\subsubsection{Identification of zooplankton sample}

For proper identification of zooplankton, $1 \mathrm{ml}$ of zooplankton sample was taken and poured into Sedgwick-Rafter counting chamber, allowed to settle sometime and observed under light microscope with proper magnification (such as X10, X40). Zooplankton were identified by referring the standard manuals and textbooks ${ }^{(14-18)}$.

\subsubsection{Analysis of parameter}

1. Temperature of reservoir - Measured by thermometer

2. $\mathrm{PH}$ of the water - Measured by digital $\mathrm{pH}$ meter

3. Free $\mathrm{CO}_{2}$ level of water- Estimated by APHA method

4. Dissolved $\mathrm{O}_{2}$ - Estimated by Winkler's method 


\subsubsection{Statistical Analysis}

Statistical analysis was performed by 'Student's t-test'. In this test, 0.05 probability, degree of freedom, critical tvalue, and calculated t-values were recorded. Here zooplankton densities along with physico-chemical parameters were observed. From these t-values, significant seasonal variations were found in the respective water body. In this experiment, at 0.05 probabilities with degree of freedom 3, critical $t$-value is 3.84 , calculated $t$-values between the two month of each season are: July'18-Aug'18: calculated t-value is 0.67, null hypothesis is accepted; Apr'19-May'19: calculated t-value is 1.116, null hypothesis is accepted; Dec'19-Jan'20: calculated t-value is 0.81, null hypothesis is accepted. Here calculated t-values in every season are less than critical t-value, so null hypothesis is accepted. Thus there is no significant change of zooplankton diversity found in a particular season. But when data was compared between two seasons at 0.05 probabilities, degree of freedom 3.84, then calculated t-values between two seasons are as follows: in monsoon-winter season: Calculated t-value is 8.527, so it rejects null hypothesis; in Post-monsoon winter season: Calculated t-value is 7.35, so it also rejects null hypothesis. Thus when data were compared according to season wise, it is found that calculated $t$-value is higher than the critical $t$ - value. So it rejects the Null hypothesis and accepts the alternative hypothesis. From the analysis of t-test, it is concluded that the number of zooplankton significantly varies from season to season along with the change of parameters like temperature, $\mathrm{pH}$, dissolved $\mathrm{O}_{2}$ and free $\mathrm{CO}_{2}$ level of the pond.

\section{Results and Discussions}

In the present investigation at Baburpukur, generally four different numbers of species of zooplankton such as Daphnia, Cyclops, Cypris and Brachionus were recorded. Quantitative analysis of zooplankton with physicochemical properties (temperature of reservoir, $\mathrm{pH}$ of water, free $\mathrm{CO}_{2}$ level of water and dissolved $\mathrm{O}_{2}$ of the water body) indicates that the abundance of zooplankton number and it greatly changes accordingly with the particular season. The physicochemical parameters were represented in Table 1 and the diversity of zooplankton species were represented in Table 2. In the present study, it is found that zooplankton population density greatly varies with the physiochemical parameters of the water body. It is also found that seasonal variations have an important role in the fluctuations of physicochemical parameters of Baburpukur. The physicochemical parameters and nutrient pattern play an important role in the species composition and distribution of plankton ${ }^{(19,20)}$. From the present study it is estimated that zooplankton composition greatly depends on the physicochemical parameters.

Table 1. Monthly variation of physicochemical parameters of Baburpukur

\begin{tabular}{llllllllll}
\hline Parameters & Jul-18 & Aug-18 & Sept-18 & Mar-19 & Apr-19 & May-19 & Dec-19 & Jan-20 & Feb-20 \\
\hline Temperature ofwater $\left(0^{\circ} \mathrm{C}\right)$ & 30 & $28^{\circ} \mathrm{C}$ & $21^{\circ} \mathrm{C}$ & $25^{\circ} \mathrm{C}$ & $29^{\circ} \mathrm{C}$ & $35^{\circ} \mathrm{C}$ & $12^{\circ} \mathrm{C}$ & $10^{\circ} \mathrm{C}$ & $13^{\circ} \mathrm{C}$ \\
pH of water & 7.0 & 7.0 & 7.1 & 6.9 & 6.8 & 6.7 & 7.0 & 7.2 & 7.1 \\
Dissolved $\mathrm{O}_{2}(\mathrm{mg} / \mathrm{l})$ & 6.58 & 6.24 & 6.15 & 6.60 & 6.62 & 6.64 & 5.24 & 5.07 & 5.97 \\
Free $\mathrm{CO}_{2}(\mathrm{mg} / \mathrm{l})$ & 25.43 & 25.80 & 24.7 & 25.87 & 25.9 & 26.7 & 23.9 & 23.14 & 24.12 \\
\hline
\end{tabular}

Table 2. Monthly and seasonal abundance of zooplankton at Baburpukur

\begin{tabular}{llllllllll}
\hline Zooplankton Species & Jul-18 & Aug-18 & Sept-18 & Mar-19 & Apr-19 & May-19 & Dec-19 & Jan-20 & Feb-20 \\
\hline Daphnia & 24 & 19 & 19 & 21 & 23 & 29 & 17 & 15 & 18 \\
Cyclops & 20 & 21 & 17 & 18 & 19 & 25 & 15 & 14 & 16 \\
Cypris & 18 & 17 & 15 & 22 & 25 & 21 & 14 & 13 \\
Brachionus & 15 & 16 & 12 & 07 & 09 & 12 & 09 & 09 & 15 \\
Total No & 77 & 73 & 63 & 68 & 76 & 86 & 55 & 51 & 59 \\
\hline
\end{tabular}

The correlation between number of zooplankton species and temperature is presented here. Physiological, metabolic activities and distribution of aquatic organisms generally depends on water temperature ${ }^{(21-23)}$. The number of zooplankton increases significantly with the increasing temperature. In winter season, when the temperature of water 
body is $10^{\circ} \mathrm{C}$, the total number of zooplankton is $51 / 100 \mathrm{ml}$ of water. But in summer season, when the water temperature raised up to the level of $35^{\circ} \mathrm{C}$, the total number of zooplankton also increases to $86 / 100 \mathrm{ml}$ of water. It suggests that higher temperature helps to increase the number of zooplankton species of this water body.

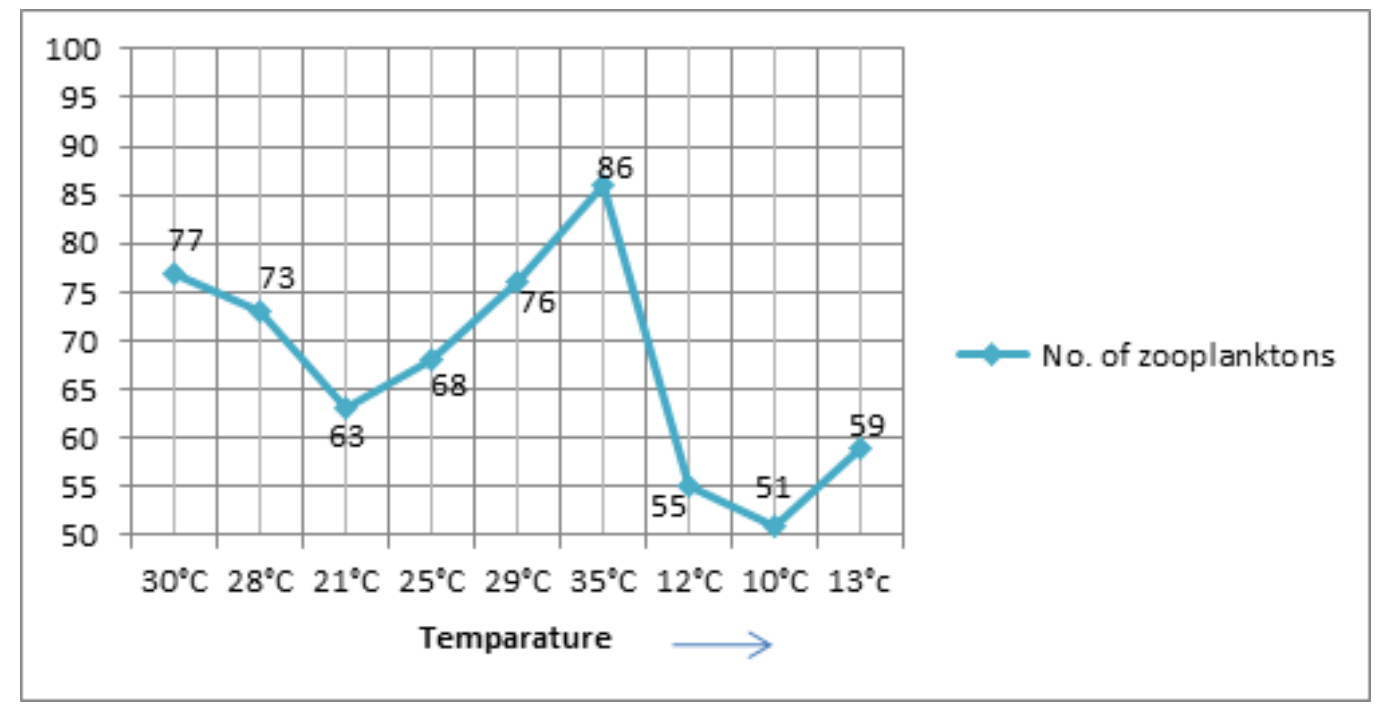

Fig 1. Effect of temperature on zooplankton density

In case of $\mathrm{pH}$, zooplankton number is highest when the $\mathrm{pH}$ is low; in May'2019 when the $\mathrm{pH}$ of water is 6.7 the total zooplankton is $86 / 100 \mathrm{ml}$ of water but in January'2020 when the $\mathrm{pH}$ of water is 7.2 , then the number of total zooplankton is $51 / 100 \mathrm{ml}$ of water. So the change of $\mathrm{pH}$ in the water body is significantly affecting the density of zooplankton population. Maximum $\mathrm{pH}$ in any condition increases photosynthesis due to high temperature resulting in higher consumption of carbon dioxide in the pond ecosystem ${ }^{(24)}$. In this experiment we also found high $\mathrm{pH}$ decreases the zooplankton density.

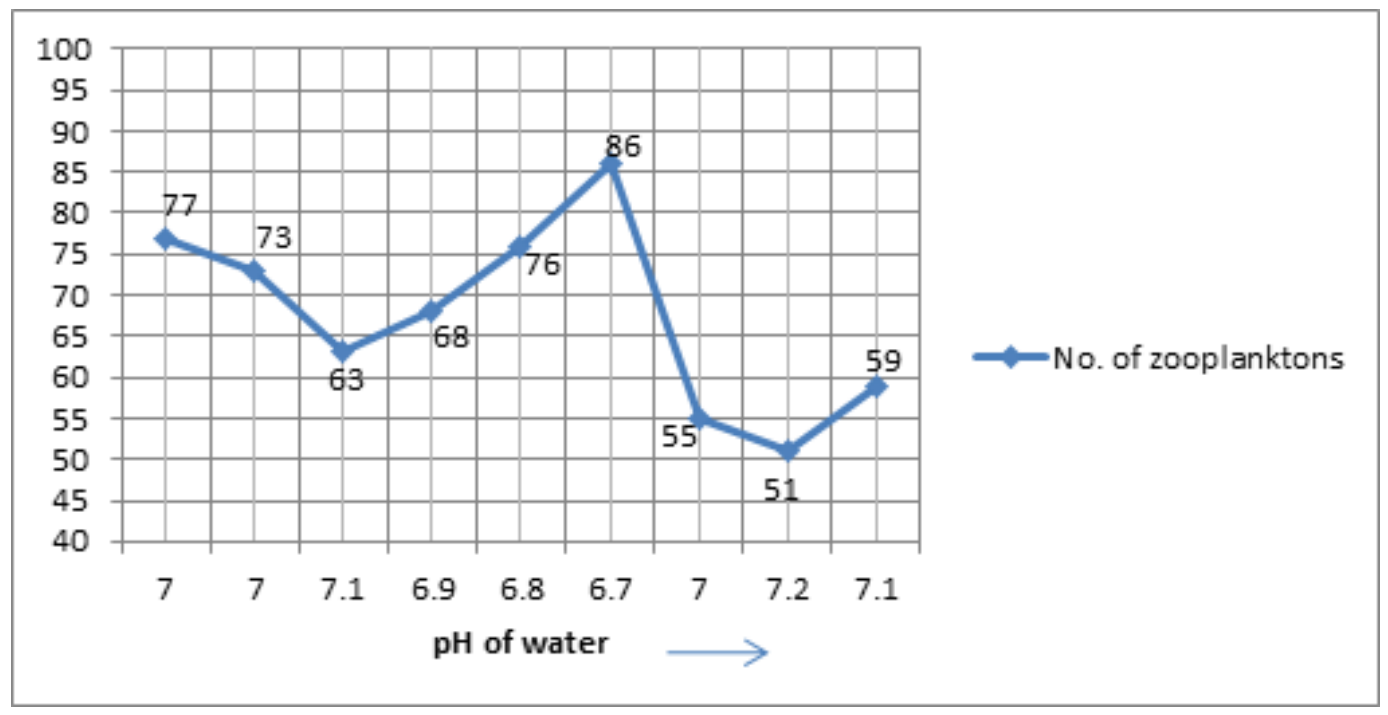

Fig 2. Effect of $\mathrm{pH}$ on zooplankton density

The value of free $\mathrm{CO}_{2}$ in this experiment ranged between $23.9 \mathrm{mg} / 1$ to $26.7 \mathrm{mg} / \mathrm{l}$. The maximum free $\mathrm{CO}_{2}$ was recorded generally in summer and minimum was recorded in winter ${ }^{(25)}$. It suggested that maximum $\mathrm{CO}_{2}$ concen- 
tration is in the month of March. It was also noticed that free $\mathrm{CO}_{2}$ level of water plays an important role in zooplankton density. With the higher level of free $\mathrm{CO}_{2}$, as in the month of May, 2019, the number of zooplankton is high, i.e. $86 / 100 \mathrm{ml}$ of sample; but in January, 2020 , at $23.14 \mathrm{mg} / \mathrm{l}$ of free $\mathrm{CO}_{2}$ concentration, the number of zooplankton is $51 / 100 \mathrm{ml}$ of sample. So from this data it was found that high $\mathrm{CO}_{2}$ concentration in the water body helps to increase the zooplankton density.

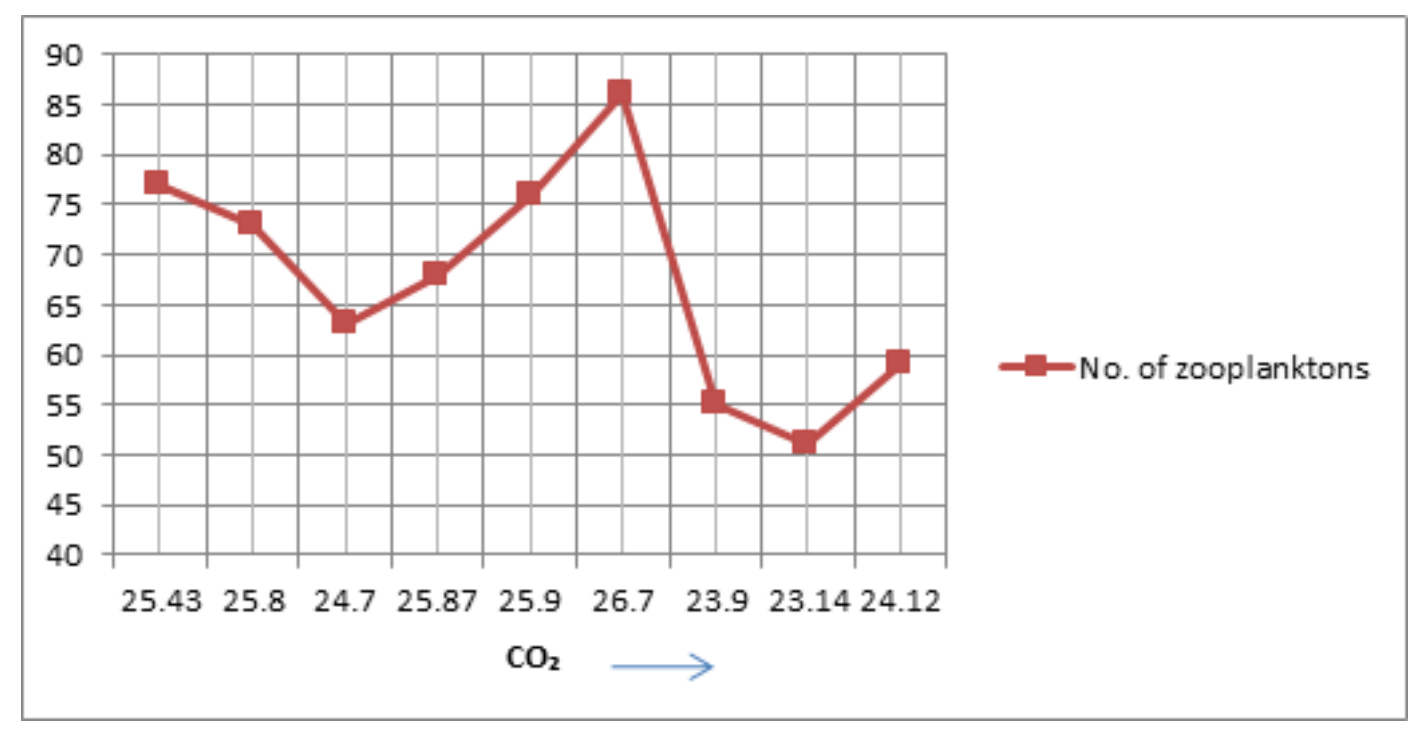

Fig 3. Effect of carbon dioxide on zooplankton density

In case of dissolved $\mathrm{O}_{2}$ level which indicates water quality and diversity of living organisms, it was found that in summer May'2019 the total zooplankton number is $86 / 100 \mathrm{ml}$ of sample where dissolved $\mathrm{O}_{2}$ is the highest, $6.64 \mathrm{mg} / 100 \mathrm{ml}$ but in Jan' $2020, \mathrm{O}_{2}$ level is $5.07 \mathrm{mg} / 100 \mathrm{ml}$ and the total number of zooplankton species is $51 / 100 \mathrm{ml}$ of sample. So, it is found that zooplankton number is proportional to the dissolved $\mathrm{O}_{2}$ level. The minimum value of dissolved oxygen was found in the month of January and maximum in the month of May ${ }^{(26)}$.

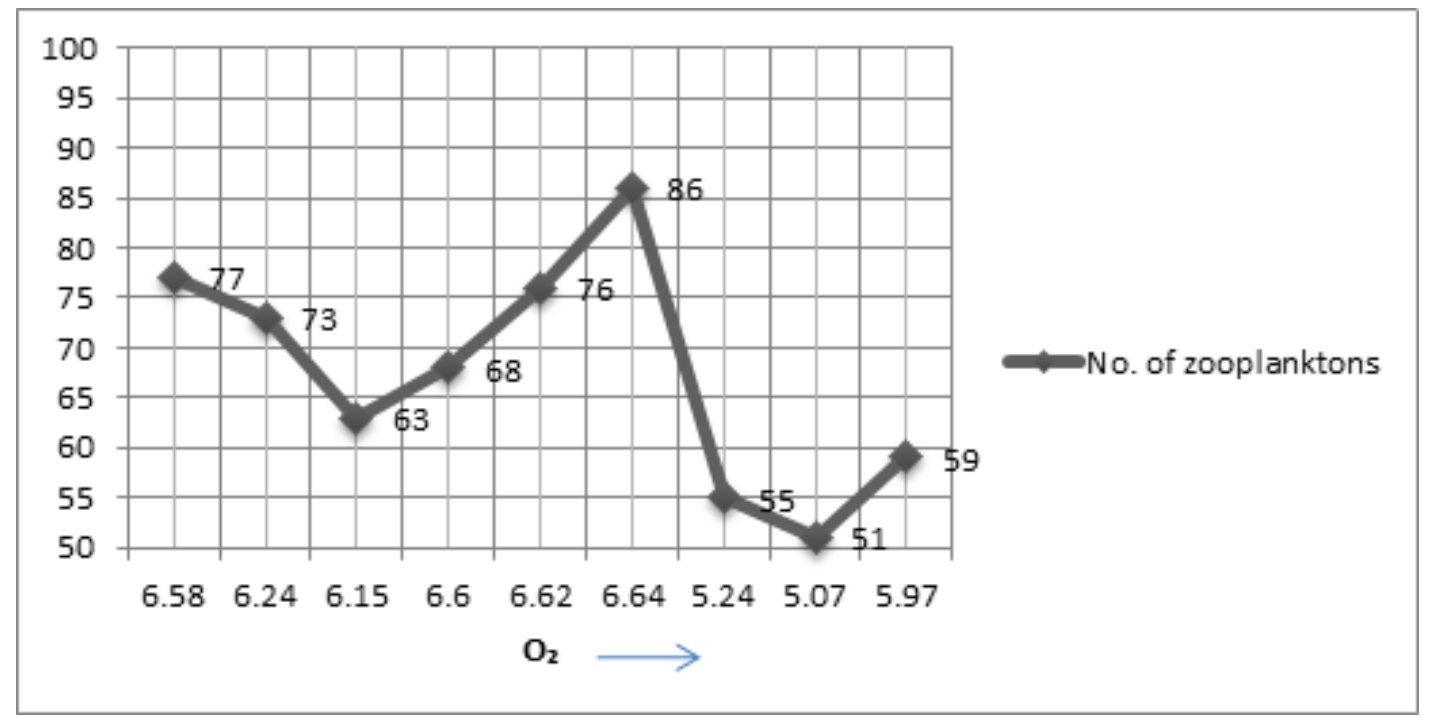

Fig 4. Effect of dissolve $\mathrm{O}_{2}$ on zooplankton density 


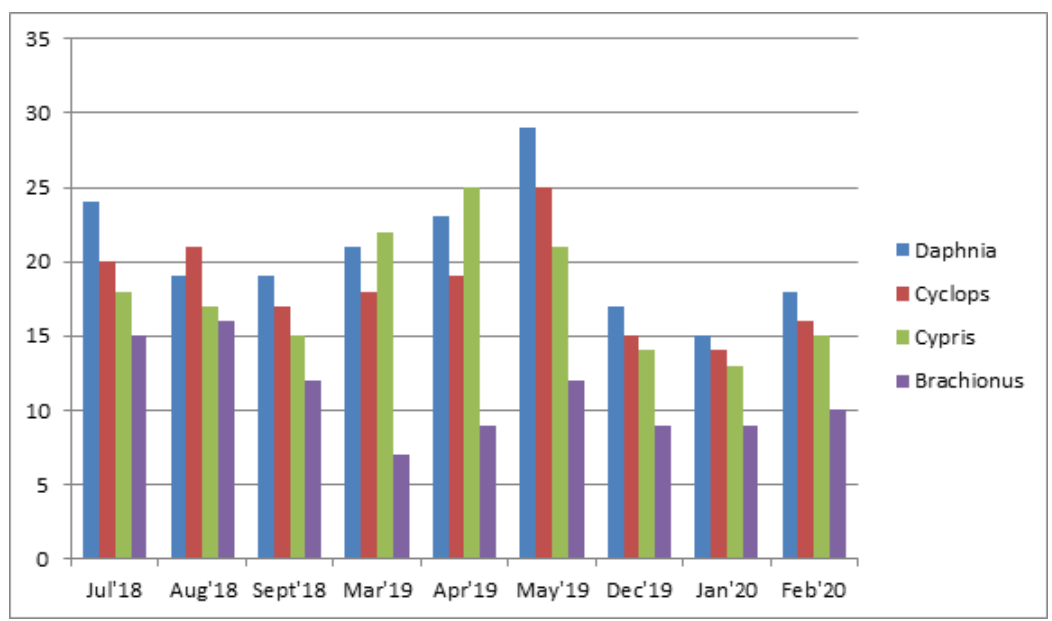

Fig 5. Seasonal variation of zooplankton species at Baburpukur, West Bengal

From the present study it was found that in the summer months, zooplankton density was generally high because of the favorable environmental conditions and also availability of nutrients in the pond ecosystem. High nutrient enrichment helps to increase the number of phytoplankton which ultimately increases zooplankton density ${ }^{(27)}$. From the present study it was found that increased temperature also increased the rate of evaporation, photosynthesis and ultimately more nutrient concentration in the water body which accelerates zooplankton density but when temperature falls, zooplankton density also decreases. At present this water reservoir is suitable for fish culturing. If zooplankton number falls, then food chain of total pond ecosystem will diminish. So several management practices are necessary to conserve this zooplankton density for proper healthy situation of water body. Recently several DNA -based methods have been invented for proper identification of zooplankton species and their density in freshwater ecosystem ${ }^{(28)}$. Zooplankton diversity is also considered to be strategic component of freshwater aquatic ecosystem and it maintains aquatic food webs ${ }^{(29)}$. This study is helpful in understanding the zooplankton diversity of Baburpukur Pond with proper maintenance of aquaculture. Limitations of the present study: Zooplankton may exist in a wide range of environmental conditions but temperature, $\mathrm{pH}$, dissolved $\mathrm{O}_{2}$ and free Carbon dioxide level of water are the limiting factors. The number of zooplankton in freshwaters is continuously changing in space and time. This changing pattern ultimately makes it difficult to estimate their abundance in the collected samples.

\section{Conclusion}

Zooplankton density was observed to peak during summers but it was least during monsoons. But during rainy season, the sudden fall of temperature and mineral dilution decreases their numbers ${ }^{(30-32)}$. In aquatic ecosystems, zooplankton plays an important role not only converting plant material to animal food but also acts as a food source for higher organisms. The zooplankton density of this habitat was found to be dominated by Daphnia followed by Cyclops, Cypris and Brachionus. The highest zooplankton number in the month of summer may be due to phytoplankton increase, decaying vegetation and also increased level of organic matter in the water body. In the future study, complete biotic enumeration would help in understanding the interplay of zooplankton, phytoplankton and abiotic factor for preserving aquatic biodiversity. Therefore, the present investigation on quantitative analyses of zooplankton in this aquatic ecosystem is the first step towards this direction.

\section{References}

1) Howick GI, Wilhm J. Zooplankton and benthic macroinvertebrates in Lake Carl Blackwell. In: and others, editor. Proceedings of Okla Academy of Science;vol. 64. 1984;p. 63-65. 
2) Padmavati G, Goswami C. Zooplankton ecology in the Mandovi-Zuari estuarine system of Goa, West coast of India. Indian Journal of Marine Sciences. 1996;25:268-273.

3) Alahuhta J, Erös T, Kärnä OM, Soininen J, Wang J, Heino J. Understanding environmental change through the lens of trait-based, functional, and phylogenetic biodiversity in freshwater ecosystems. Environmental Reviews. 2019;27(2):263-273. Available from: https: //dx.doi.org/10.1139/er-2018-0071. doi:10.1139/er-2018-0071.

4) Ali MM, Islam MA, Habib MAB. Monthly abundance of zooplankton and correlation of various dominant species and nauplius of zooplankton with some water characters in a pond. University Journal of Zoology, Rajshahi Univ. 1985;4:42-49.

5) Caroni R, Irvine K. THE POTENTIAL OF ZOOPLANKTON COMMUNITIES FOR ECOLOGICAL ASSESSMENT OF LAKES: REDUNDANT CONCEPT OR POLITICAL OVERSIGHT? Biology \& Environment: Proceedings of the Royal Irish Academy. 2010;110(1):35-53. doi:10.3318/bioe.2010.110.1.35.

6) Kehayias G, Chalkia E, Doulka E. Zooplankton variation in five greek lakes. Kehayias G, editor;New York.. Zooplankton Nova Science Publishers. Inc. 2014.

7) Jose EC, Furio EF, Borja VM, Gatdula NC, Santos DM. Zooplankton composition and abundance and its relationship with physicochemical parameters in Manila Bay. Oceanography. 2015;3(1):1-6. doi:10.4172/2332-2632.1000136.

8) Smitha P, Shivashankar GV, Venkataramana. Zooplankton diversity of Chikkadevarayana Canal in relation to physico-chemical characteristics. Journal of Environmental Biology. 2013;34(4):819-824.

9) Bhagat VB, Meshram CB. Seasonal variations of zooplankton abundance in Ambadi Dam, of Akot, District- Akola (M.S). Bioscience Biotechnology Research Communications. 2010;2(2):215-221.

10) Steinberg DK, Landry MR. Zooplankton and the Ocean Carbon Cycle. Annual Review of Marine Science. 2017;9(1):413-444. doi:10.1146/annurev-marine-010814-015924.

11) Sharma BK, Pachuau L. Zooplankton diversity of a sub-tropical reservoir of Mizoram Northeast India. Opuscula Zoologica. 2013;44(1).

12) Amalesh B, Dutta TK, Patra BC, Sar UK. A Study on Zooplankton Biodiversity of Kangsabati Reservoir, W.B., India. International Journal of Developmental Research. 2014;4:2431-2436.

13) APHA. Standard methods for the examination of water and waste water. 21st ed. Washington, D.C. 2005.

14) Edmondson WT. Freshwater biology. 2nd ed. New York. John Wiley \& Sons, Inc. 1959.

15) Altaff K. A manual of zooplankton. 2004.

16) Battish SK. Freshwater zooplankton of India. Oxford and IBH Publication Co.. 1992;p. 1-231.

17) Murugan N, Murugavel P, Kodarkar MGL. Cladocera. Indian Association of Aquatic Biologist Hyderabad. 1998;5:1-55.

18) Sharma BK, Michael RG. Review of taxonomic studies on freshwater Cladocera from India with remarks on biogeography. Hydrobiologia. 1987;145(1):29-33. Available from: https://dx.doi.org/10.1007/bf02530262. doi:10.1007/bf02530262.

19) Horne AJ, Goldman CR. Limnology;vol. 2. New York. McGraw-Hill. 1994.

20) Mahar MA, Baloch WA, Jafri SIH. Diversity and seasonal occurrence of planktonic rotifers in Manchharlake. Pakistan Journal of Fisheries. 2000;1(1):25-32.

21) Bhavan PS, Selvi A, Manickam N, Srinivasan V, Santhanam P, Vijayan P. Diversity of zooplankton in a perennial Lake at Sulur, Coimbatore, India. International Journal of Educational Research. 2015;5:31-44.

22) Manickam N. Biodiversity of plankton in two perennial lakes of Coimbatore, India and suitability of wild mixed zooplankton as live feed for rearing of the giant freshwater prawn Macrobrachium rosenbergii early post larvae. Coimbatore. 2015.

23) Manickam N, Bhavan PS, Santhanam P. Evaluation of nutritional profiles of wild mixed zooplankton in Sulur and Ukkadam Lakes of Coimbatore, South India. Turkish Journal of Fisheries and Aquatic Sciences. 2017;17(3):509-517. doi:10.4194/1303-2712-v17_3_07.

24) Jakher GR, Rawat M. Studies on physico-chemical parameters of a tropical lake. International Journal of Aquatic Biology. 2003;18(2):7983.

25) Telkhade PM, Dehegaonkar NR, Zade SB. Water Quality Assessment of Nerinala at Durgapur Distt. Chandrapur of Maharashtra. Envirnment conservation Journal. 2008;9(1 and 2):49-53.

26) Mani B, Gaikwad SK. Physico-chemical characteristics of Lake Pokhran . Indian Journal of Environment and Toxicology. 1998;8(2):56-58.

27) Manickam N, Bhavan PS, Santhanam P, Muralisankar T, Srinivasa V, Radhakrishnan S. Seasonal variations of zooplankton diversity in a perennial reservoir at Thoppaiyar. Journal of Aquaculture \& Marine Biology. 2014;1(1):1-7.

28) Xiong W, Huang X, Chen YF, Ruiying DX, Chen X, Zhan A. Zooplankton Biodiversity Monitoring in Polluted Freshwater Ecosystems: A technical review. Environmental Science and Ecotechnology. 2019;1(1).

29) Chakrabarty M, Banerjee A, Mukherjee J, Rakshit N, Ray S. Spatial pattern analysis of zooplankton community of Bakreswar reservoir, India. Energy, Ecology and Environment. 2017;2(3):198-206. Available from: https://dx.doi.org/10.1007/s40974-017-0057-8. doi:10.1007/s40974-017-0057-8.

30) Coman FE, Connolly RM, Preston NP. Zooplankton and epibenthic fauna in shrimp ponds: factors influencing assemblage dynamics. Aquaculture Research. 2003;34(5):359-371. doi:10.1046/j.1365-2109.2003.00898.x.

31) Chakraborty I. Limnology and zooplankton abundance in selected wetlands of Nadia District of West Bengal. Environment and Ecology. 2004;22:576-578.

32) Dutta SPS, Khullar M, Sharma J. Limnology of two springs adjacent to Chattha Nullah Jammu part III: Zooplankton. The Ecoscan. 2010;4:197-205. 